\begin{tabular}{c} 
Volume and Issues Obtainable at Center for Sustainability Research and Consultancy \\
Journal of Accounting and Finance in Emerging Economies \\
ISSN: 2519-0318 ISSN (E) 2518-8488 \\
Volume 5: Issue 1 June 2019 \\
CSRᄃ \\
Journal homepage: www.publishing.globalcsrc.org/jafee \\
\hline
\end{tabular}

\title{
Does Mandatory IFRS adoption and Macroeconomic Factors Affect Cost of Equity Capital? Empirical Evidence from South African Listed Firms
}

\author{
${ }^{1}$ Michael Yeboah, ${ }^{2}$ Andrast Akacs \\ ${ }^{1}$ Kumasi Technical University Ghana, Email address: yebomich@ gmail.com \\ ${ }^{2}$ University Of PECS, Hungary, Email address: takacsandras@ktk.pte.hu
}

\begin{tabular}{l} 
ARTICLE DETAILS \\
\hline History \\
Revised format: May 2019 \\
Available Online: June 2019 \\
\\
\hline Keywords \\
IFRS Adoption, Cost Of Equity \\
Capital; Macroeconomic Factors; \\
Fixed Effects; South Africa
\end{tabular}

JEL Classification:

G3, G30, G32

ABSTRACT

Purpose: This paper investigates the collaboration of International Financial Reporting Standards (IFRS) adopted and macroeconomic variables interaction with information asymmetry, analysts following and managerial opportunism affecting the cost of equity capital, and also influence investor's decision taking on companies in South Africa.

Design/Approach: A sample of 49 listed Johannesburg mining and manufacturing firms was extracted from archival database of INET BFA/IRESS SA, Morningstar, and Anupedia. A leverage fixed effects panel data set of firms from 2001 to 2014 was examined, which shows that Breusch-Lagrange Multiplier tests and the test of over-identifying restrictions used, form the basis of the content analysis of the most recent IFRS effect after mandatory adoption. We used a hand-collected dataset between 2000 and 2015.

Findings: Our findings suggest that a significant association is found between IFRS and its interactions with managerial opportunism and integrity but with a reasonable statistical effect. However, the IFRS adoption effect on the cost of equity capital of South African firms' has no significant effect.

Practical implications: This study reveals that most firms report more, the credibility of annual financial statements which may not be sufficient because of the qualitative data for an assessment of managerial opportunism, information asymmetry and analysts following. Of such myopia of company managers, their reputation causes agency problems and as a result, shareholders interest is mainly focused on improving reporting standards

Originality: The research considers dual harmonizing facets: first, that the interaction with IFRS adoption and economic factors impact on the cost of equity capital may be so pathetic and obvious; and second, that IFRS moderation impacts on the cost of equity capital in Sub- Saharan African. This finding should be meaningful to managers, analysts, policymakers, and supervisory bodies in nations with similar capital structure decisions and socioeconomic systems.

(C) 2019 The authors, under a Creative Commons Attribution-Non Commercial 4.0

Corresponding author's email address: yebomich @ gmail.com

Recommended citation: Yeboah, M. and Akacs, A.(2019). Does Mandatory IFRS adoption and Macroeconomic 
Factors Affect Cost of Equity Capital? Empirical Evidence from South African Listed Firms. Journal of Accounting and Finance in Emerging Economies, 5 (1), 57-70

DOI: $10.26710 /$ jafee.v5i1.725

\section{Introduction}

Globalization has resulted in many countries devising means of becoming very competitive to avoid being left out. Therefore, one means used by countries is the improvement of the financial reporting standards. Thus, several nations have adopted IFRS, which is established by the International Accounting Standards Board (IASB). The intended aim of IFRS is a mechanism that should give way to a greater demand for the firm value required by investors and other stakeholders in their quest for financial reporting quality (Jonas \& amp; Blanchet, 2000). Prior extant literature links cost of equity capital of IFRS adoption, which obliges listed companies in South Africa to prepare annual reports in conformity to IFRS since 2005.

IFRS is to strengthen corporate reporting and its relation to firms cost of equity capital, which has become a phenomenon of interest (Madhani 2008). Thus, IFRS adoption will increase the credibility of financial reporting and create investment opportunities which would reduce the costs of equity capital and improve the return on investment. The implication to adopt IFRS on stock market aspects of cost of equity capital boils down to the essence of financial information to the users and stock market development (Francis et al., 2006). It, therefore, follows that IFRS should reduce the cost of equity capital because it reduces managerial opportunism and information asymmetry whiles it increases analyst following of adopted firms. So there is a growing debate on whether IFRS adoption and the cost of equity capital are either complementary or substitutes the approaches to value creation. Therefore, this study emphases on how the cost of equity capital of listed manufacturing and mining firms in South Africa has changed after IFRS adoption.

South Africa was the first African countries to adopt IFRS, therefore studies of this nature attract several researchers' attention and also being the most important economy in Africa for investment opportunities, hence the reason for its selection. Despite, after a decade of IFRS adoption in South Africa, there is scanty information about capital structure decisions. This paper examines IFRS adoption and macroeconomic factors impact on the cost of equity capital of South Africa listed manufacturing and mining companies.

The argument on whether companies attribute to the cost of equity capital reduction in information quality is an important and contentious problem for corporate managers, capital market players, and information quality standard setters to establish.

Our estimation is the financial statement data covering the period 2001 to 2014 of 49 South Africa listed manufacturing and mining firms. We estimated the panel data regression method applied to estimate the effect of IFRS adoption on the cost of equity capital and also use control variables as a technique to make it possible for unobserved heterogeneity that correlates with explanatory variables.

Our study reveals that IFRS and its interactions with other variables had no significant effect on the firms' cost of equity capital. We interpret this negative relation because firms find it expensive to implement new efficiency standards. However, managerial opportunism, integrity, and the exchange rate have an inverse relationship with firms' cost of equity capital. This paper, therefore concludes, that IFRS adoption had no meaningful impact on the selected listed firms' cost of equity capital in South Africa.

This paper draws on recent advances in IFRS adoption literature and firm's cost of equity capital in relation to financial reporting quality and economic factors. Our findings give an insight of IFRS adoption influences on the agent-principal relationship of resource accountability between the owners of the business and those accused of governance. Failed IFRS implementation undermines quality financial reporting and therefore appears to result in unfortunate shareholders indifference.

Therefore, this study contributes to a growing finance and accounting literature on IFRS adoption and firms' cost of equity capital in the following ways. First, most research on IFRS adoption and firms' cost of equity capital was focused on European data. This study uses manufacturing and mining industries of South Africa that is sensitive and therefore offers a better understanding of this relationship. Second, this study recognizes managerial opportunism, analyst following, and information asymmetry as the moderation role of IFRS adoption and firms' 
cost of equity in the South African context. Third, this paper utilizes both firm-level and macroeconomic factors as controlling variables from a broader perspective to explain the firms' cost of equity capital as against prior studies. Fourth, this study is first of its kind to allow for longer transition periods (early post-adoption 2006-2009 and late post-adoption 2011-2014) in IFRS adoption effect on the cost of equity capital, as against previous studies (Houqe et al. (2015); Gatsios et al. (2016); Patro and Gupta (2014); Castillo-Merino et al., 2014; and Daske (2014).

Besides the introduction, the rest of the paper is structured as follows. Section two reviews relevant literature on IFRS adoption and firms cost of equity capital and the development of research hypotheses. Section three presents the specified method. Section four discusses the empirical results and conclusion, while proposals for future research form the fifth section.

\section{Theoretical Underpinnings and Hypotheses Development \\ 2.1 Accounting Standard- Settings in South Africa}

South Africa is at the same time a code and a common-law nation where investor protection and insider/market positioning opened. The Accounting Standards Board (ASB) is prepared by a legislative instrument, whose main aim is to set standards for all spheres of government, accompany by directives and guidelines. Minister of Finance, in collaboration with the Auditor-General, seek to implement the new standards and ensure complete compliance with the standards. The South African Institute of Chartered Accountants (SAICA) is responsible for managing all accounts setting processes. Because ASB is consider best accounting practices that have the quality to enhance capital markets for foreign investment (Liener, 1995), the International Financial Reporting Standards (IFRS) is approved in 2005. Under this, listed firms prepare financial statements in complying with IFRS. The new standards are to be of quality; therefore it is an opportunity to examine the effect of the cost of equity capital and the adoption.

\subsection{Conceptual Backgrounds}

IFRS adoption dwells on two theories, the bonding theory of adoption explains the increasing trend of individual firm's fame associated with the financial markets (Coffee, 2002), while the signaling theory stipulates that firm's commitment to quality financial reporting is built on a signal for IFRS adoption (Tarca, 2002). International Accounting Standards Board (IASB) develops IFRS to be acceptable in the world for developing accounting activities, thus promoting accounting rules harmonization. There is an extensive relationship between the quality of IFRS adoption on financial accounting information of listed South African manufacturing and mining companies and to reduce the cost of equity capital and improved investment returns (Tweedie 2006, and Barth et al. 2008). Large numbers of accounting quality indicators associated with IFRS adoption by European countries have enhanced the reporting credibility (Chen et al., 2010; Barth et al., 2008). Paramount to corporate decisions is an entity's cost of equity capital. From defining the target rate for investment plans to influence corporate capital structure decisions, the cost of equity capital effects on firm's operations and its subsequent cost-effectiveness. Given this importance, it is not surprising that a wide range of policy recommendations has been an innovation to help businesses reduce this cost (Easley and O'hara, 2004).

The cost of equity capital is expected to decrease in two ways. First, international comparability of financial statements ought to improve in relation to IFRS adoption of a general accounting 'language'. This entices equity from foreign investors and therefore reduces the barriers to cross-border equity flows. Second, the corporate disclosure must improve when better-quality accounting standards are adopted to the local GAAP which is of lower quality. This enables outside investors to monitor investment returns when information asymmetry is being reduced and improved accounting standards should reduce the costs of equity capital (Core et al. 2011). According to Levitt (1998), the veracity is that high-quality standards would lower the cost of capital.

\subsection{Hypotheses Developments}

Cost of equity capital: According to Daske et al. (2008), the benefits of capital markets are achieved when firms present credible annual reports. Most specifically, comparability benefits among investors is a question of considerable interest and significance to the financial reporting community. However, the association between accounting information quality and the cost of equity capital is not well addressed and has proved difficult to conclude. It is a fact that most of the benefits following IFRS adoption are linked with Europe. It is not appropriate to accept that the results can be generalized to apply to African situations. 


\subsubsection{Cost of Equity Capital and IFRS Interaction With Information Asymmetry}

Signaling theory identifies problems relating to information asymmetry in capital markets and also illustrates how it causes alarm to investors (Morris, 1987). Akerlof (1970) shows that, in the existence of unaware buyers, value prices are based on perceptions about products but not on their quality.

Agency theory heightens information asymmetry between those charged with governance and the owners of the business. Information asymmetry focuses on the disclosure of inside information to benefit managers at the expense of shareholders. IFRS mandatory enjoins the management to disclose all material items as part of the financial statements to avoid distortion of information for decision making. An incentive to shift to IFRS may suggest better economic performance and firm value, under reduced information asymmetry. This sort is to reconcile diverse / contradictory findings on information asymmetry impact on the cost of equity in conjecture market situations wherein imperfect markets information asymmetry cause risk factors (Armstrong, et al. 2011). In an international research, Hail and Leuz (2006) concludes that nations with a better information environment have a lower cost of equity capital. IFRS adoption of listed manufacturing and mining firms in South Africa increases information asymmetry which decreases inherent conflict of interest, reducing the cost of equity capital. Hence, we have a positive relationship between the cost of equity capital and IFRS interaction with information asymmetry and hypothesize that:

Hypothesis 1: Combined effect of IFRS-adopted firms and information asymmetry pertains to reducing the cost of equity capital than firms under a pre-adoption period.

\subsubsection{Cost of Equity Capital and IFRS Interaction With Analysts Following}

Both public and private sources of information needed by investors are supplied by financial analysts. This information is important in order to aid in capital market development (Healy and Palepu, 2001). Therefore, financial analysts are used as an intermediary between investors and firms (Schipper, 1991). Investors rely on financial analysts to find out more about a firm and to make investment portfolio decisions. IFRS adoption improves public disclosure and reduces the costs of getting information which tends to increase the analysts following firms. Analyst following is invoked as a proxy for the richness of a firm's information environment (Lys and Soo, 1995; Bae et al. 2008; Brown and Higgins, 2002). In a more concentrated study, a reduced cost of equity capital is a combined function of analyst following forecast properties and IFRS. In summary, higher combine effect of analyst following and IFRS adoption enables the environment to improve capital structure decisions. The hypothesis is:

Hypothesis 2: Combined effect of IFRS-adopted firms and analyst following is positively associated with the decreased cost of equity capital than firms under the pre-adoption period.

\subsubsection{The Cost of Equity Capital and IFRS Adoption Interaction With Managerial Opportunism}

Williamson (1985) noted that opportunism is "self-interest seeking with guile". Managerial opportunism is an inevitable consequence of costly information. In the world of no transaction cost, including the cost of determining behavior and actions of stewards (managers), there would be no opportunism. In another direction, the study examines whether the shift to IFRS reduces managerial opportunism. Quality of financial reporting expects under IFRS as the different standards heighten informative disclosure and promote investor protection mechanisms. We posit that IFRS adoption would lead to lowering managerial opportunism (Luez, 2003; Latridis and Rouvolis, 2010). We anticipated an adverse relationship with the cost of capital of firms and their interaction with IFRS adoption and managerial opportunism. The hypothesis tested is:

Hypothesis 3: Interaction effect of IFRS-adopted firms and managerial opportunism are negatively associated with lower cost of equity capital than firms under the pre-adoption period.

\subsubsection{Macroeconomic Factors and IFRS Adoption}

Quality of macroeconomic factors under the IFRS adoption has a negative impact and reduces the effect on firm's cost of equity capital (Wang and Welker, 2011). This underlines the score that macroeconomic factors are high and that accounting systems would develop so as to motivate investors based on firms' performance, all things being equal (Li, 2010 and Castillo-Merino et al., 2014). Despite that from all the studies above, none of them was done in Africa. We expect macroeconomic factors under IFRS adoption to increase shareholders' value in the country. Based on this argument, we hypothesize that: 
Hypothesis 4: Quality macroeconomic factors decrease the cost of equity capital under IFRS adoption.

\section{Research Design}

\subsection{Sample and Dataset Selection}

The population for this study is mining and manufacturing firms listed on the JSE. The characteristics of the listed firms enhance the research since they report in a similar format for the study periods. However, sample companies must meet the conditions below:

- The companies that have been consistently listed on the JSE for fifteen years prior to the research.

- Firms that have consistently published annual reports within the study period.

Applying these standards resulted in a sample of 49 companies (refer to table 1).

The empirical analysis was based on data retrieved from the annual financial statements of 49 listed companies on the JSE during a fourteen-year periods, 2001- 2014. Fourteen years were selected because these were apt to test before and after adoption. In all, 686 firm-years reports of listed manufacturing and mining companies for the period 2001-2014 were utilized. The sample companies are those firms that have consistently published annual reports and showed existing information before and after the adoption periods.

The companies' annual financial data were downloaded from archival databases of INET BFA/IRESS SA, Morningstar, and Anupedia. Table 1 shows that sampled firms represent $75.39 \%$ of the total population.

Table 1: sample selection process

\begin{tabular}{|l|l|l|}
\hline \multicolumn{2}{|c|}{ Firm/Year obs. } \\
\hline Initial sample of observations: Manufacturing & 38 & \\
Mining & 27 & 100 \\
& 65 & -18.46 \\
\hline Firms with insufficient observations: Manufacturing & $(12)$ & -6.15 \\
\hline Final sample & $(4)$ & 75.39 \\
\hline
\end{tabular}

We used firm's specific control variables as IFRS adoption in South Africa is mandatory for all listed reporting entities. There are no other firms that use alternative accounting standards after the obligatory adoption period for comparison. Therefore, the 49 listed firms in a standardized firm-year observation was used to explain pre-adoption and the post-adoption periods. It is very likely that the change observed on firms' cost of equity capital was linked to IFRS adoption. Firm-specific factors are controlled by having the same requirements.

Four separate periods of data were employed in the study; the pooled (2001-2014), a pre-adoption (2001-2004), the early post-adoption (2006-2009), and the late post-adoption period of 2011-2014. These approaches ensure that data covering the four reporting periods under IFRS for all firms have an equal number of observations for preIFRS and post-adoption periods (Chua et al., 2012), except for the pooled regression model which uses 2001 to 2014 years excluding 2005 period. The exclusion of 2005 as the adoption of transitional year is consistent with Chua et al. (2012) and Zeghal et al. (2012).

Table 2: Description of Variables and Sources

\begin{tabular}{|c|c|c|}
\hline Variables & Description/ measurement & Source (s) \\
\hline \multicolumn{3}{|l|}{ Dependent var } \\
\hline $\begin{array}{l}\text { Cost of Equity } \\
\text { Capital (LNCOEC) }\end{array}$ & $\begin{array}{l}\text { =Market price per share (MPPS)/ Earnings per share } \\
\text { (EPS) in natural logarithm } \\
\text { where; } \\
\text { MPPS=share price (MPS)/ total share outstanding } \\
\text { (T.SHS) in natural logarithm } \\
\text { EPS=turnover (TUROV)/ total share outstanding } \\
\text { (T.SHS) in natural logarithm }\end{array}$ & $\begin{array}{l}\text { Walter A. Morton (1970). } \\
\text { hwww.economicsdiscussion.net }\end{array}$ \\
\hline $\begin{array}{l}\text { Managerial } \\
\text { Opportunism }\end{array}$ & $\begin{array}{l}\text { Earnings management measured as discretionary } \\
\text { accrual (i.e. residuals from total accrual) in natural }\end{array}$ & Modified Jones Model \\
\hline
\end{tabular}




\begin{tabular}{|c|c|c|}
\hline (LNMO) & $\begin{array}{l}\text { logarithm } \\
\text { formula: } \\
D A=T A-\left(\beta_{0}+\beta_{1 t} \frac{1}{A_{i, t-1}}+\beta_{2 t} \frac{\Delta \operatorname{Rev}_{i, t}-\Delta \operatorname{Rec}_{i, t}}{A_{i, t-1}}+\right. \\
\left.\beta_{3 t} \frac{P P E_{i, t}}{A_{i, t-1}}\right)\end{array}$ & \\
\hline $\begin{array}{l}\text { Information } \\
\text { Asymmetry (LNIA) }\end{array}$ & $\begin{array}{l}\text { Bid-Ask spread measured by high and Low share } \\
\text { price in natural logarithm }\end{array}$ & Corwin and Schultz (2010) \\
\hline $\begin{array}{ll}\text { Analyst } & \text { Following } \\
\text { (LNAF) } & \end{array}$ & $\begin{array}{l}\text { Number of analysts actively tracking and publishing } \\
\text { an opinion on firm and its stock; i.e handy } \\
\text { collection in natural logarithm }\end{array}$ & The INET BFA Database \\
\hline IFRS & $\begin{array}{l}\text { Pre-adoption (2001-2004), early adoption (2006- } \\
\text { 2009) and late-adoption (2011-2014). }\end{array}$ & Author's Design \\
\hline $\begin{array}{l}\text { Macroeconomic } \\
\text { factors }\end{array}$ & $\begin{array}{l}\text { Interest rate (LNIR) (bank rate: the rate at which } \\
\text { Central Bank of South Africa lends to the } \\
\text { commercial banks) } \\
\text { Exchange rate (LNEX) (RAND to dollar rate) } \\
\text { Gross Domestic Product (GDP)[GDP at constant } \\
\text { price (\% change)] } \\
\text { Bankruptcy(LNBR) } \\
\text { Government borrowing (LNGOVB) (Government } \\
\text { net debt as a \% of GGP] } \\
\text { Integrity (LNINTG) } \\
\text { (All variables are in their natural logarithms) }\end{array}$ & $\begin{array}{l}\text { Fred. Stlouisfed.org } \\
\text { Federalreserve.org } \\
\text { Resbank.co.za/World } \\
\text { Development Indicators } \\
\text { The Global Economy-South } \\
\text { Africa. } \\
\text { Worldwide governance } \\
\text { indicators }\end{array}$ \\
\hline Control variables & $\begin{array}{l}\text { Leverage (LNLEV) equal to the total debt divided } \\
\text { by total asset) in natural logarithm } \\
\text { Liquidity (LQ): ratio of current asset to current } \\
\text { liability in natural logarithm } \\
\text { Tangibility (TANG): Ratio of net plant proper } \\
\text { equipment to total asset in natural logarithm }\end{array}$ & $\begin{array}{l}\text { Badertscher et al. (2014) } \\
\text { Baker and Martin (2011) } \\
\text { Breuer et al. (2012) }\end{array}$ \\
\hline
\end{tabular}

\subsection{Control Variables}

In accordance with previous literature, we applied three control variables with the aim of avoiding bias results. The control variables used includes; leverage, liquidity, and tangibility. The inclusion of control variables is expected to correlate with cost of equity capital estimation as their exclusion from the tests may bias the coefficients estimated.

\subsubsection{Leverage (Lev)}

Important governance mechanism includes management of debt (Shleifer and Vishny, 1997). Due to the interest and principal payments on debts, managers are liable to generate cash flow to meet them. It, therefore, ensures credible financial reporting standard to manage liability arrangements. To meet such commitments, managers make an incentive programme to increase earnings. We made use of the ratio of total debt divided by total assets (Zamri et al., 2013) to calculate leverage (LEV) (Mahoney et al., 2008). Lower leverage level expects under IFRS adoption as full disclosure of information is obligatory, therefore corporate value would be higher (Tu, 2012; Daske et al., 2008).

\subsubsection{Liquidity (LQ)}

It shows how companies could meet their financial obligations in the short-term when they fall due (Fabozzi et al., 2010-RRB). Liquidity heightens if there are fewer costs to convert company's assets into cash. Higher firm value is reached under IFRS adoption, when the adoption limits managerial accounting manipulations, but can maintain cash flow for satisfying short-term commitments (Gitman, 2004).

\subsubsection{Asset Tangibility (TANG)}

Akintoye (2009) stipulates that, keeping large investments tangible assets of firms associates with smaller costs of financial distress, will impact the optimum performance. This enhances and generates more revenue from sales. We 
measured Tangibility as the Net Property, Plant, and Equipment divided by Total Assets and in percentage form. IFRS adoption shows a positive relationship with asset tangibility and firms' cost of equity capital.

\subsection{Model Specifications And Analysis Techniques}

Since the data were a panel, the pooled ordinary least square regression (POLS), a random effects (RE) and a fixed effects (FE) estimation were used depending on which is the best. This is tantamount to select the best econometric model that can lead to correct inferences arising from coefficient estimates (Onali et al., 2017). Therefore, the Breusch and Pagan Lagrangian multiplier test are used to select between the RE and the POLS regression, and if the RE is the better option. To assess the validity of usable instruments, the Sargan test of over-identifying restrictions (Sargan-Hansen statistic) chooses between the RE and the FE. The test of over-identifying restrictions is used for the study controlled for heteroskedasticity by using robust standard errors and hence the Hausman test would not have been appropriate. However, if the POLS are ahead of the RE, the F-test chooses between the POLS and the FE. In comparing the POLS to FE, the FE is run without a robust standard error option to display the F-test result. Therefore, if the test chose the FE model ahead of the POLS, the FE is re-run with the robust standard error option. Thus, in this study, all standard errors were robust catering for any possible heteroskedasticity. Therefore, the empirical models used are as shown in equations 1 and 2, where equation 1 is used for the pooled data of 20012014 periods, excluding 2005 the adoption year. The data for pooled regression period are denoted by equation 1 as follows:

$$
\begin{aligned}
& \operatorname{coec}_{\text {it }}=\propto_{0}+\propto_{1} \operatorname{tang}_{\text {it }}+\propto_{2} \mathrm{LQ}_{\mathrm{it}}+\propto_{3} \operatorname{lev}_{\mathrm{it}}+\propto_{4} \mathrm{IA}_{\mathrm{it}}+\propto_{5} \mathrm{AF}_{\mathrm{it}}+\propto_{6} \mathrm{MO}_{\mathrm{it}}+\propto_{7} \text { IFRS } * \mathrm{IA}_{\mathrm{i}, \mathrm{t}}+\propto_{8} \text { IFRS } * \mathrm{AF} \text { it } \\
& +\propto_{9} \text { IFRS } * \mathrm{MO}_{\mathrm{i}, \mathrm{t}}+\propto_{10} \text { INTG }_{\text {it }}+\propto_{11} \mathrm{IR}_{\mathrm{it}}+\propto_{12} \mathrm{EX}_{\mathrm{it}}+\propto_{13} \text { govb }_{\text {it }}+\propto_{14} \mathrm{BR}_{\mathrm{it}}+\propto_{15} \text { IFRS }_{\text {it }}
\end{aligned}
$$

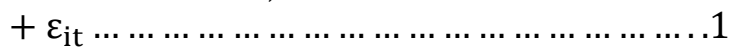

$$
\begin{aligned}
& \operatorname{coec}_{\mathrm{i}, \mathrm{t}}=\propto_{0}+\propto_{1} \operatorname{tang}_{\mathrm{it}}+\propto_{2} \mathrm{LQ}_{\mathrm{it}}+\propto_{3} \mathrm{lev}_{\mathrm{it}}+\propto_{4} \mathrm{IA}_{\mathrm{it}}+\propto_{5} \mathrm{AF}_{\mathrm{it}}+\propto_{6} \mathrm{MO}_{\mathrm{it}}+\propto_{7} \mathrm{INTG}_{\mathrm{it}}+\propto_{8} \mathrm{IR}_{\mathrm{it}}+\propto_{9} \mathrm{EX}_{\mathrm{it}}
\end{aligned}
$$

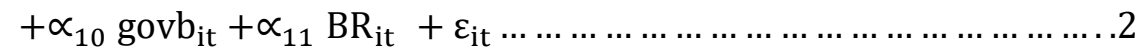

$$
\begin{aligned}
& \operatorname{coec}_{\mathrm{i}, \mathrm{t}}=\propto_{0}+\propto_{1} \operatorname{tang}_{\mathrm{it}}+\propto_{2} \mathrm{LQ}_{\mathrm{it}}+\propto_{3} \mathrm{lev}_{\mathrm{it}}+\propto_{4} \mathrm{IA}_{\mathrm{it}}+\propto_{5} \mathrm{AF}_{\mathrm{it}}+\propto_{6} \mathrm{MO}_{\mathrm{it}}+\propto_{7} \mathrm{IR}_{\mathrm{it}}+\propto_{8} \mathrm{EX}_{\mathrm{it}}+\propto_{9} \text { govb }_{\mathrm{it}}
\end{aligned}
$$

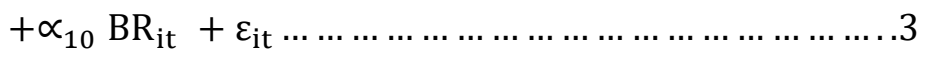

$$
\begin{aligned}
& \operatorname{coec}_{\mathrm{i}, \mathrm{t}}=\propto_{0}+\propto_{1} \operatorname{tang}_{\mathrm{it}}+\propto_{2} \mathrm{LQ}_{\mathrm{it}}+\propto_{3} \mathrm{lev}_{\mathrm{it}}+\propto_{4} \mathrm{IA}_{\mathrm{it}}+\propto_{5} \mathrm{AF}_{\mathrm{it}}+\propto_{6} \mathrm{MO}_{\mathrm{it}}+\propto_{7} \mathrm{INTG}_{\mathrm{it}}+\propto_{8} \mathrm{IR}_{\mathrm{it}}+\propto_{9} \mathrm{EX}_{\mathrm{it}}+
\end{aligned}
$$

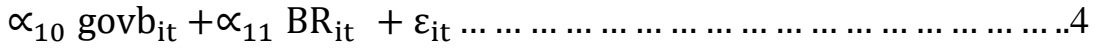

The meanings of all the notations were set out, and it must be emphasized that all the variables were used in their natural logarithm forms (LN) except IFRS and its interactions with other variables. Furthermore, all analyses in this study needed to be done using STATA 11.2 and 14 versions.

\section{Empirical Results and Discussion}

This section covered analysis and discussion on correlation analysis, as well as regression results.

\subsection{Descriptive Statistics And Correlation Analysis}

This section covered descriptive variables and correlation analysis of the study, i.e. the standard deviation, mean, minimum and maximum values of variables employed in the study as well as the strength of association between the variables.

Table 3: Descriptive Statistics of used Variables

\begin{tabular}{llllll}
\hline Variable & Mean & Std. Dev. & Min & Max & Observ. \\
\hline Coec overall & .0048982 & .0339538 & $2.34 \mathrm{e}-08$ & .445382 & $\mathrm{~N}=637$ \\
Between & .0278361 & $1.50 \mathrm{e}-07$ & .1924169 & & $\mathrm{n}=49$ \\
Within & & .019815 & -.0720787 & .416017 & $\mathrm{~T}=13$ \\
Tang overall & .4233627 & .2217169 & -.9939135 & 1.485497 & $\mathrm{~N}=637$ \\
Between & & .1573793 & .1578005 & .901558 & $\mathrm{n}=49$ \\
Within & & .1576624 & -1.018307 & 1.212745 & $\mathrm{~T}=13$ \\
LQ overall & 1.656138 & 1.162449 & .1543981 & 19.45693 & $\mathrm{~N}=637$ \\
\hline
\end{tabular}




\begin{tabular}{|c|c|c|c|c|c|}
\hline Between & & .5433952 & .4174591 & 3.79206 & $\mathrm{n}=49$ \\
\hline Within & & 1.03033 & -.3953993 & 18.37016 & $\mathrm{~T}=13$ \\
\hline Lev overall & .3536813 & .3536813 & .1112685 & 1.349616 & $\mathrm{~N}=637$ \\
\hline Between & & .1123075 & .2085788 & .8583845 & $\mathrm{n}=49$ \\
\hline Within & & .2131733 & -.1899268 & 1.075835 & $\mathrm{~T}=13$ \\
\hline IA overall & .3356972 & .4432782 & 0 & 8.5604 & $\mathrm{~N}=637$ \\
\hline Between & & .1599642 & .0938 & .8744538 & $\mathrm{n}=49$ \\
\hline Within & & .4139926 & -.4980182 & 8.021643 & $\mathrm{~T}=13$ \\
\hline $\mathrm{AF}$ overall & 4.954474 & 3.248047 & 2 & 12 & $\mathrm{~N}=637$ \\
\hline Between & & 1.210563 & 2.538462 & 7.153846 & $\mathrm{n}=49$ \\
\hline Within & & 3.018609 & -.1993721 & 11.87755 & $\mathrm{~T}=13$ \\
\hline AF overall & 4.954474 & 3.248047 & 2 & 12 & $\mathrm{~N}=637$ \\
\hline Between & & 1.210563 & 2.538462 & 7.153846 & $\mathrm{n}=49$ \\
\hline Within & & 3.018609 & -.1993721 & 11.87755 & $\mathrm{~T}=13$ \\
\hline MO overall & .0023402 & .6518441 & -12.78741 & 6.846503 & $N=636$ \\
\hline Between & & .1106116 & -.4706663 & .2900195 & $\mathrm{n}=49$ \\
\hline Within & & .6425592 & -12.31441 & 7.31951 & $\mathrm{~T}-\mathrm{bar}=12.9796$ \\
\hline INTG overall & 3.966154 & .4946873 & 3.3 & 5 & $\mathrm{~N}=637$ \\
\hline Between & & 0 & 3.966154 & 3.966154 & $\mathrm{n}=49$ \\
\hline Within & & .4946873 & 3.3 & 5 & $\mathrm{~T}=13$ \\
\hline IR overall & 7.885777 & 2.28305 & 4.94 & 12.73 & $N=637$ \\
\hline Between & & .1112641 & 7.687692 & 8.006923 & $\mathrm{n}=49$ \\
\hline Within & & 2.280388 & 4.878085 & 12.69885 & $\mathrm{~T}=13$ \\
\hline EX overall & 8.230195 & 1.668219 & 5.645 & 24.8112 & $\mathrm{~N}=637$ \\
\hline Between & & .1922378 & 8.068615 & 9.279608 & $\mathrm{n}=49$ \\
\hline Within & & 1.657316 & 5.510033 & 23.76179 & $\mathrm{~T}=13$ \\
\hline Govb overall & $2.22 \mathrm{e}+07$ & $7.68 \mathrm{e}+07$ & 19.25307 & $2.88 \mathrm{e}+08$ & $N=637$ \\
\hline Between & & $3.76 \mathrm{e}-09$ & $2.22 \mathrm{e}+07$ & $2.22 \mathrm{e}+07$ & $\mathrm{n}=49$ \\
\hline Within & $7.68 \mathrm{e}+07$ & 19.25307 & $2.88 \mathrm{e}+08$ & & $\mathrm{~T}=13$ \\
\hline BR overall & 116.4615 & 43.25186 & 55 & 191 & $\mathrm{~N}=637$ \\
\hline Between & & 0 & 116.4615 & 116.4615 & $\mathrm{n}=49$ \\
\hline Within & 43.25186 & 55 & 191 & & $\mathrm{~T}=13$ \\
\hline IFRS overall & .6923077 & .4619012 & 0 & 1 & $\mathrm{~N}=637$ \\
\hline Between & & 0 & .6923077 & .6923077 & $\mathrm{n}=49$ \\
\hline Within & & .4619012 & 0 & 1 & $\mathrm{~T}=13$ \\
\hline
\end{tabular}

From Table 3, cost of equity capital had an overall mean value.0048982. Also, it can be seen that the overall mean values of the variables as showed in parenthesis were liquidity (1.656138), tangibility (.4233627), leverage (.3536813), analyst following (4.954474), information asymmetry (.3356972), integrity (3.966154), managerial opportunism (.0023402), exchange rate (8.230195), interest rate (7.885777), government borrowing (2.22e+07) and bankruptcy (116.4615). Thus, bankruptcy had the highest overall mean value. In addition, results in the minimum and maximum values, number of observation and standard deviation of all variables can further be seen in Table 3 . Also, the IFRS dummy had both maximum and minimum values at 1 and 0 representing IFRS adoption periods (1) and no IFRS adoption periods (0). 
Table 4: Correlation Analysis

\begin{tabular}{|c|c|c|c|c|c|c|c|c|c|c|c|c|}
\hline Variables & Coec & Tang & LQ & Lev & IA & $\mathrm{AF}$ & INTG & IR & EX & govb & $\mathrm{MO}$ & BR \\
\hline coec & 1.0000 & & & & & & & & & & & \\
\hline $\operatorname{tang}$ & 0.0979 & 1.0000 & & & & & & & & & & \\
\hline LQ & 0.0297 & 0.0425 & 1.0000 & & & & & & & & & \\
\hline Lev & 0.0342 & 0.1660 & 0.0064 & 1.0000 & & & & & & & & \\
\hline IA & -0.0106 & -0.0238 & -0.0159 & 0.0711 & 1.0000 & & & & & & & \\
\hline $\mathrm{AF}$ & -0.0559 & -0.0241 & -0.0344 & 0.0341 & -0.0817 & 1.0000 & & & & & & \\
\hline INTG & -0.0525 & 0.0050 & 0.0026 & -0.0383 & -0.0539 & 0.0545 & 1.0000 & & & & & \\
\hline IR & 0.0321 & 0.0099 & -0.0876 & -0.0776 & -0.0892 & 0.1374 & 0.1352 & 1.0000 & & & & \\
\hline EX & 0.0407 & 0.0308 & 0.0159 & 0.0422 & 0.0738 & -0.0816 & -0.6653 & -0.0025 & 1.0000 & & & \\
\hline govb & -0.0182 & -0.0041 & 0.0279 & 0.0094 & -0.0201 & 0.0654 & 0.1186 & -0.3045 & -0.1648 & 1.0000 & & \\
\hline MO & 0.0229 & -0.0149 & -0.1991 & 0.0180 & 0.0173 & -0.0176 & -0.0181 & -0.0083 & 0.1062 & 0.0198 & 1.0000 & \\
\hline BR & 0.0553 & 0.0074 & -0.1016 & -0.1003 & -0.0936 & 0.1011 & 0.1968 & 0.8358 & -0.1677 & -0.1898 & -0.0460 & 1.0000 \\
\hline
\end{tabular}

Source: Author's Computation from Anupedia, INET BFA/RESS SA, and Momingstar, 2017. $0 \mathrm{bs}=636$

The correlation analysis as shown in Table 4 was conducted to investigate the direction and strength of relationship among the variables used in the study. Therefore, a negative sign implies that the variables move in opposite directions (negatively correlated) and a positive sign means the variables move in the same direction (positively correlated). In addition, the closer the correlation coefficient is tantamount to 1 , the greater the strength of association and the farther the correlation coefficient is to 1 , the weaker the strength of association. Therefore, the same variables would be perfectly correlated with a coefficient of 1 as seen in the results. Regarding the correlation between different variables, only the correlation between exchange rate and integrity ( -0.6653$)$, and the correlation between bankruptcy and interest rate (0.8358) was relatively stronger; negatively and positively respectively. However, the strength of the association between the remaining variables was weak generally.

Table 5: The Effect of IFRS on Cost of Equity Capital of Listed Firms in South Africa

\begin{tabular}{|c|c|c|c|c|c|c|c|}
\hline & $\begin{array}{l}\text { 2001-2014 } \\
\text { excluding } \\
\text { (FE) }\end{array}$ & 2005 & $\begin{array}{l}2001-2004 \\
(\mathrm{FE})\end{array}$ & & $\begin{array}{l}\text { 2006-2009 } \\
\text { (FE) }\end{array}$ & & $\begin{array}{l}\text { 2011-2014 } \\
\text { (FE) }\end{array}$ \\
\hline & LNcoec & & LNcoec & & LNcoec & & LNcoec \\
\hline LNtang & $\begin{array}{l}0.0806 \\
(0.139)\end{array}$ & LNtang & $\begin{array}{l}0.237 \\
(0.232)\end{array}$ & LNtang & $\begin{array}{l}0.0608 \\
(0.260)\end{array}$ & LNtang & $\begin{array}{l}-0.281^{*} \\
(0.159)\end{array}$ \\
\hline LNLQ & $\begin{array}{l}0.362 \\
(0.275)\end{array}$ & LNLQ & $\begin{array}{l}1.897 * * * \\
(0.682)\end{array}$ & LNLQ & $\begin{array}{l}0.138 \\
(0.137)\end{array}$ & LNLQ & $\begin{array}{l}0.0990 \\
(0.175)\end{array}$ \\
\hline LNlev & $\begin{array}{l}-0.0298 \\
(0.0930)\end{array}$ & LNlev & $\begin{array}{l}-0.0629 \\
(0.168)\end{array}$ & LNlev & $\begin{array}{l}-0.298^{* *} \\
(0.141)\end{array}$ & LNlev & $\begin{array}{l}0.105 \\
(0.0802)\end{array}$ \\
\hline LNIA & $\begin{array}{l}0.0716 \\
(0.106)\end{array}$ & LNIA & $\begin{array}{l}0.320 * \\
(0.172)\end{array}$ & LNIA & $\begin{array}{l}-0.177 * * * \\
(0.0545)\end{array}$ & LNIA & $\begin{array}{l}0.0323 \\
(0.0691)\end{array}$ \\
\hline LNAF & $\begin{array}{l}0.145 \\
(0.188)\end{array}$ & LNAF & $\begin{array}{l}0.135 \\
(0.165)\end{array}$ & LNAF & $\begin{array}{l}-0.0793 \\
(0.0899)\end{array}$ & LNAF & $\begin{array}{l}0.0511 \\
(0.0918)\end{array}$ \\
\hline LNMO & $\begin{array}{l}-0.0833 * * * \\
(0.0304)\end{array}$ & LNMO & $\begin{array}{l}-0.0153 \\
(0.0767)\end{array}$ & LNMO & $\begin{array}{l}-0.00418 \\
(0.0215)\end{array}$ & LNMO & $\begin{array}{l}-0.0856^{*} \\
(0.0433)\end{array}$ \\
\hline IFRSIA & $\begin{array}{l}-0.283 \\
(0.382)\end{array}$ & LNINTG & $\begin{array}{l}-1.866 \\
(1.484)\end{array}$ & LNIR & $\begin{array}{l}0.378 \\
(0.282)\end{array}$ & LNINTG & $\begin{array}{l}0.986 \\
(1.698)\end{array}$ \\
\hline IFRSAF & $\begin{array}{l}-0.00883 \\
(0.0453)\end{array}$ & LNIR & $\begin{array}{l}0.0895 \\
(1.058)\end{array}$ & LNEX & $\begin{array}{l}-1.692 * * \\
(0.730)\end{array}$ & LNIR & $\begin{array}{l}-2.107 \\
(1.470)\end{array}$ \\
\hline IFRSMO & $\begin{array}{l}-0.0296 \\
(0.141)\end{array}$ & LNEX & $\begin{array}{l}-0.678 \\
(1.857)\end{array}$ & LNgovb & $\begin{array}{l}-2.426^{* *} \\
(0.985)\end{array}$ & LNEX & $\begin{array}{l}1.367 \\
(1.811)\end{array}$ \\
\hline LNINTG & $\begin{array}{l}-2.269 * * * \\
(0.754)\end{array}$ & LNgovb & $\begin{array}{l}-1.586 \\
(1.924)\end{array}$ & LNBR & $\begin{array}{l}-0.413 \\
(0.510)\end{array}$ & LNgovb & $\begin{array}{l}0.0424 \\
(0.0368)\end{array}$ \\
\hline LNIR & 0.404 & LNBR & 1.106 & _cons & -0.410 & LNBR & -0.974 \\
\hline
\end{tabular}




\begin{tabular}{|c|c|c|c|c|c|c|}
\hline & $(0.306)$ & & $(1.023)$ & $(3.824)$ & & $\begin{array}{l}(1.032) \\
\text { (1) }\end{array}$ \\
\hline LNEX & $\begin{array}{l}-1.828 * * * \\
(0.386)\end{array}$ & _cons & $\begin{array}{l}-9.303 * * \\
(4.129)\end{array}$ & & _cons & $\begin{array}{l}-10.00 \\
(7.904)\end{array}$ \\
\hline LNgovb & $\begin{array}{l}-0.00890 \\
(0.00743)\end{array}$ & & & & & \\
\hline LNBR & $\begin{array}{l}0.205 \\
(0.384)\end{array}$ & & & & & \\
\hline IFRS & $\begin{array}{l}-0.00609 \\
(0.376)\end{array}$ & & & & & \\
\hline _cons & $\begin{array}{l}-7.516^{* * * *} \\
(1.378)\end{array}$ & & & & & \\
\hline $\mathrm{N}$ & 365 & & 104 & 111 & & 121 \\
\hline $\mathrm{R} 2$ & 0.183 & & 0.375 & 0.606 & & 0.157 \\
\hline adj. R2 & 0.148 & & 0.301 & 0.566 & & 0.072 \\
\hline $\mathrm{F}$ & 4.432 & & 4.164 & 8.273 & & 1.161 \\
\hline
\end{tabular}

Standard errors are in parentheses $+p<0.10, * p<0.1, * * p<0.05, * * * p<0.01$. LNTANG represents tangibility in natural logarithm, LNLQ represents natural logarithm of liquidity, LNLEV represents natural logarithm of leverage, LNIA represents natural logarithm of information asymmetry, LNAF represents natural logarithm of analyst following, LNMO represents natural log of managerial opportunism, LNINTG represent natural $\log$ of integrity, LNIR represents natural log of interest rate, LNEX represents natural log of exchange rate, LNGOVB represents natural log of government borrowing, and LNBR represents bankruptcy.

\section{Regression Results}

This section tackled analysis and discussion of the regression models used in attaining the objectives of the study noted in Table 5. Of all the periods/models considered, the tests (Breusch and Pagan Lagrangian multiplier test, the test of over identifying restrictions (Sargan-Hansen statistic) and an F-test) chose the fixed effect model to be the best. Therefore, the results revealed that in the 2001-2014 model, excluding 2005, managerial opportunism (LNMO) had a $1 \%$ significant coefficient of -0.0833 and hence the cost of equity capital decreased by $0.0833 \%$ when there is a $1 \%$ increase in managerial opportunism. Furthermore, the coefficient of integrity (LNINTG) was 2.269 , which was significant at $1 \%$ and hence a $1 \%$ rise in integrity led to a $2.269 \%$ decrease in firms' cost of equity capital. Also, a coefficient $(-1.828)$ of the exchange rate that was significant at $1 \%$ implies that, when exchange rate rose by $1 \%$, the cost of equity capital fell by $1.828 \%$. Thus, managerial opportunism, integrity, and the exchange rate had decreased the effects on IFRS.

However, it was disclosed that IFRS as a variable and also as its interactions with other variables have no significant impact on firms' cost of equity capital and hence the null hypothesis could not be rejected. Our result agrees with the findings of Gatsios et al. (2016) which revealed that IFRS adoption does not decrease firms' cost of equity capital in Brazil. Daske (2014) who didn't find lower anticipated cost of equity capital for IAS/IFRS adopters as well as the result of Patro and Gupta (2014) who found IFRS to have no significant influence on the cost of equity capital of Chinese and Israeli firms. Never the less, the results contradict those of Houqe et al. (2015) who found IFRS adoption to have a negative impact on the cost of equity capital as well as those of Castillo-Merino et al. (2014) who revealed a negative significant impact with IFRS adoption and the cost of equity capital of Spanish listed firms.

With regard to the Pre-IFRS adoption period (2001-2004), only information asymmetry (LNIA) and liquidity (LNLQ) were significant at $10 \%$ and $1 \%$ respectively. Therefore, given their respective coefficients of 0.320 and 1.897 implied that a $1 \%$ increase in information asymmetry and liquidity led to a $0.320 \%$ and $1.897 \%$ increase in the firms' cost of equity capital (coec) respectively. Information asymmetry and liquidity had positive impacts on the cost of equity capital. Regarding an early IFRS adoption period (2006-2009), leverage (LNlev) was found to have a 5\% significant coefficient of -0.298 and hence cost of equity capital fell by $0.298 \%$ when leverage increased by $1 \%$. Moreover, a $1 \%$ rise in information asymmetry was found to decrease the cost of equity capital by $0.177 \%$ bestowed its $1 \%$ significant coefficient of -0.177 . Also, it was revealed that an increase in the exchange rate would cause the cost of equity capital of firms' to decrease. Thus, a $1 \%$ rise in the exchange rate was found to reduce firms' cost of equity capital by $1.692 \%$ since the exchange rate had a $5 \%$ significant coefficient of -1.692 . In addition, government borrowing had a decreasing impact on the cost of equity capital given its $5 \%$ significant 
coefficient of -2.426 . Thus, a $1 \%$ increase in government borrowing would reduce firms' cost of equity capital by $2.426 \%$.

Last but not the least, in the late IFRS adoption period (2011-2014), tangibility and managerial opportunism had $10 \%$ significant coefficients of -0.281 and -0.0856 respectively. Thus $1 \%$ increases tangibility and managerial opportunism led to $0.281 \%$ and $0.0856 \%$ decrease in cost of equity capital respectively.

\section{Conclusion}

From the findings, it can be said that, even though managerial opportunism, integrity, and the exchange rate have negative effects on the firms' cost of equity capital, IFRS adoption with its interaction with other variables had no significant impacts on the cost of equity capital among listed firms in South Africa. This requests that the need to realign the adoption to suit African economies in order to reap its numerous anticipated benefits, which include a reduced cost of equity capital. It further sends signals to other African economies on the need to tread cautiously in embarking on mandatory adoption of IFRS.

\section{Conflict of Interest}

The authors declare no competing interest.

\section{References}

Akerlof, G.A., 1970. The market for" lemons": Quality uncertainty and the market mechanism. The quarterly journal of economics, pp.488-500.

Akintoye, I.R., 2009. Sensitivity of performance to capital structure. Banking and Finance Letters, 1(1), p.29.

Armstrong, C.S., Core, J.E., Taylor, D.J. and Verrecchia, R.E., 2011. When does information asymmetry affect the cost of capital? J Account Res, 49(1), pp.1-40.

Badertscher BA, Givoly D, Katz SP, and Lee H (2014). Private Ownership and the Cost of Debt: Evidence from the Bond Market.

Bae, K.H., Tan, H. and Welker, M., 2008. International GAAP differences: The impact on foreign analysts. The Accounting Review, 83(3), pp.593-628.

Baker, H.K. and Martin, G.S., 2011. Capital structure and corporate financing decisions: theory, evidence, and practice (Vol. 15). John Wiley \& Sons.

Barney, J.B., Ketchen Jr, D.J. and Wright, M., 2011. The future of resource-based theory: revitalization or decline? J. manage.37(5), pp.1299-1315.

Barth, M.E., Landsman, W.R. and Lang, M.H., 2008. International accounting standards and accounting quality. J Account Res, 46(3), pp.467-498.

Bhushan, R. (1989): "Firm Characteristics and Analysts Following” J Account Econ, 11, pp. 255-274.

Botosan, C. (1997): "Disclosure Level and the Cost of Equity Capital" Accounting

Review. 72 (3), pp. 323-349.

Breuer, A., Frumusanu, M.L., Breuer, B.L. and Manciu, A., 2012. Cash and Liquidity/Liquidity and Liquidity Ratio. Annals-Economy Series, 4, pp.78-82.

Brown, L.D. and H.N. Higgins. 2002. "Managers' guidance of analysts: International evidence." Working paper, Georgia State University and Worcester Polytechnic Institute.

Castillo-Merino D, Menendez-Plans, C., and Orgaz -Guerrero, N. (2014). Mandatory IFRS adoption and the cost of equity capital: Evidence from Spanish firms; Intangible Capital. 10(3), pp. 562-583.

Chen, H., Tang, Q., Jiang, Y. and Lin, Z., 2010. The role of international financial reporting standards in accounting quality: Evidence from the European Union. J Int Fin Manag Acc, 21(3), pp.220-278.

Chua, Y.L., Cheong, C.S. and Gould, G., 2012. The impact of mandatory IFRS adoption on Research, 11(1), pp.119-146.

Coffee, J., 2002. Competition among securities markets: a path dependent perspective.

Corwin, S.A. and Schultz, P., 2012. A simple way to estimate bid-ask spreads from daily high and low prices. The Journal of Finance, 67(2), pp.719-760. 
Daske, H., Hail, L., Leuz, C., \& Verdi, R. (2008). Mandatory IFRS reporting around the world: Early evidence of the economic consequences. J Account Res, 46(5):1085-1142.

Daske, H. (2014). Economic Benefits of Adopting IFRS or US-GAAP: Have the Expected Costs of Equity Capital really decreased? Working Paper Series: Finance \& Accounting, No. 131.

Easley, D. and O'hara, M., 2004. Information and the cost of capital. The journal of finance, 59(4), pp.1553-1583.

Fabozzi, F.J., Focardi, S.M. and Kolm, P.N., 2010. Quantitative equity investing: Techniques

and strategies. John Wiley \& Sons.

Francis, J., LaFond, R., Olsson, P., Schipper, K. (2005). The market pricing of accruals quality. Journal of Accounting and Economics, 39(2):295- 327.

Frankel, R.M., McNichols, T., and Wilson, G. P. (1995). Discretionary disclosure and external financing. The Accounting Review (January).

Gatsios, R.C., Da Silva, J.M., Ambrozini, M.A., Neto, A.A., \& Lima, F.G. (2016). Impact of adopting IFRS standard on the equity cost of Brazilian open capital companies,Ram, Rev. Adm. Mackenzie, 17(4), 85108.

Garcia Lara, J.M., GarcíaOsma, B. and Penalva, F., 2010. Accounting conservatism and firm investment efficiency.

Hail, L. and Leuz, C., 2006. International differences in the cost of equity capital: Do legal institutions and securities regulation matter? J Account Res, 44(3), pp.485-531.

Han, F. \& He, H. (2013). Cost of equity capital of foreign firms did bonding benefits diminish after the SEC's waiver of IFRS to US GAAP reconciliation? Review of Accounting and Finance12 (3), 2013 pp. 268-285. DOI 10.1108/RAF-Nov-2011-0044.

Healy, P.M. and Palepu, K.G., 2001. Information asymmetry, corporate disclosure, and the capital markets: A review of the empirical disclosure literature. J Account Econ, 31(1-3), pp.405-440.

Houqe, M.N., Monem, R.M. and van Zijl, T., 2016. The economic consequences of IFRS adoption: Evidence from New Zealand. Journal of International Accounting, Auditing and Taxation, 27, pp.40-48.

Iatridis, G. and Rouvolis, S., 2010. The post-adoption effects of the implementation of International Financial Reporting Standards in Greece. Journal of international accounting, auditing and taxation, 19(1), pp.55-65.

Jonas, G.J. and Blanchet, J., 2000. Assessing quality of financial reporting. Accounting Horiz, 14(3), pp.353-363.

Leung, R.W.T., 2013. Cost of equity effects from mandatory IFRS adoption: the importance of reporting incentives (Doctoral dissertation, Heriot-Watt University).

Levitt, A., 1998. The importance of high quality accounting standards. Accounting horiz, 12(1), p.79.

Li, S (2010). Does mandatory adoption of International Financial Reporting Standards in the European Union reduce the cost of equity capital?' The Accounting Review, vol 85 pp, 607-636.

Gitman L.J., Principles of Managerial Finance, 4th ed., Pearson Addison Wesley, Boston, 2006.

Liener, G., 1995. Accounting standards required of global corporations by the international capital markets. ZeitschriftfürBetriebswirtschaft, 65, pp.741-751.

Lowe, H.D., 1967. Accounting aid for developing countries. The Accounting Review, 42(2), pp.356-360.

Luez, C., 2003. IAS Versus US GAAP: Information Asymmetry-Based Evidence from Germany's market. J Account Res, 41(3).

Lys, T. and Soo, L.G., 1995. Analysts' forecast precision as a response to competition. Journal of Accounting, Auditing \& Finance, 10(4), pp.751-765.

Madhani, P (2008) Corporate Disclosure: Concepts and Practices (first ed). Hyderabad, India: ICFAI University Press.

Mahoney, L., LaGore, W. and Scazzero, J.A., 2008. Corporate social performance, financial performance for firms that restate earnings. Issues in Social and Environmental Accounting, 2(1), pp.104-130.

Morris, R.D., 1987. Signaling, agency theory and accounting policy choice. Account Bus Res, 18(69), pp.47-56.

Patro, A. \& Gupta, V.K. (2014). Impact of International Financial Reporting Standards on Cost of equity Capital for Asian countries. International Journal of Accounting and Financial Reporting, 4(2). 
Patro, A. and Gupta, V.K., 2016. Impact of International Financial Reporting Standards on Stock Price Synchronicity for Asian Markets. Contemporary Management Research, 12(1).

Schipper, K., 1991. Analysts' forecasts. Accounting horiz, 5(4), p.105.

Shleifer, A. and Vishny, R.W., 1997. A survey of corporate governance. The journal of finance, 52(2), pp.737-783.

Smart, S.B., Megginson, W.L. and Gitman, L.J., 2004. Corporate finance. Mason, OH: Thomson/South Western.

Tarca, A., 2002. Achieving international harmonisation through accounting policy choice.

Tu, C.J., 2012. The Impact of Stocks Index Adjustments Announcement on Earnings Management. International Journal of Economics and Finance, 4(11), p.91.

Tweedie, D., 2006. Prepared statement of Sir David Tweedie, Chairman of the International Accounting Standards Board before the Economic and Monetary Affairs Committee of the European Parliament. See: http://www. iasplus. Com/resource/0601tweedieeuspeech. Pdf.

Walter A. Morton (1970). The Investor Capitalization Theory of the Cost of Equity Capital. Land Economics, Vol. 46, No. 3. pp. 248-263 Published by: University of Wisconsin Press.

Wang, S. and Welker, M., 2011. Timing equity issuance in response to information asymmetry arising from IFRS adoption in Australia and Europe. J Account Res, 49(1), pp.257-307.

Williamson, O., 1985. E., 1985, The Economic Institutions of Capitalism: firms, markets, relational contracting. New York.

World Investment Report 2007 (WIR07) is the seventeenth in a series published by the United Nations Conference on Trade and Development (UNCTAD).

Zeghal, D., Chtourou, S.M. and Fourati, Y.M., 2012. The effect of mandatory adoption of IFRS on earnings quality: Evidence from the European Union. Journal of International Accounting Research, 11(2), pp.1-25.

Zamri, N., Rahman, R.A. and Isa, N.S.M., 2013. The impact of leverage on real earnings management. Procedia Economics and Finance, 7, pp.86-95. 
